\title{
Constraining the dynamics of volcanic eruptions by characterization of pumice textures
}

\author{
Margherita Polacci \\ Istituto Nazionale di Geofisica e Vulcanologia, Sede di Pisa, Italy
}

\begin{abstract}
We have characterized the textures of pumice clasts from Phlegraean Fields to gain insights into the conduit flow-dynamics of alkaline explosive eruptions. Vesicularities, vesicle number densities, and vesicle sizes and shapes were measured to obtain the bulk and groundmass properties of the juvenile fraction of Campanian Ignimbrite (CI) and Agnano Monte Spina (AMS) eruptions. The results report the coexistence of three end-member pumice types in the deposits of both eruptions, 1) microvesicular, 2) tube and 3) expanded, which differ according to clast morphology and the macro- to microscopic vesicle texture. Vesicularities (0.85-0.94 for CI, 0.51-0.91 for AMS) and vesicle number densities $\left(2-4 \times 10^{5} \mathrm{~cm}^{-2}\right.$ in CI, $3 \times 10^{5}-10^{6} \mathrm{~cm}^{-2}$ in AMS) span quite a wide range in all the three pumice types. Overall, tube pumices exhibit the highest bulk (0.89) and groundmass (CI 0.85, AMS 0.82) average vesicle volume fractions but the lowest average vesicle number densities (CI $2 \times 10^{5}$, AMS $4 \times 10^{5} \mathrm{~cm}^{-2}$ ). Comparison with textures of calc-alkaline pumices has revealed many similarities and points to a common origin and distribution of the products from both magma compositions within the volcanic conduit. In addition, the results of the textural analysis were interpreted in the light of the conduit flow modeling of Phlegraean Fields eruptions. The comparison of textural observations with results from simulations of conduit magma ascent has exhibited a good agreement between measured and numerically calculated vesicularities for both compositions, helping to constrain the overall dynamics of alkaline versus calc-alkaline eruptions.
\end{abstract}

Key words Phlegraean Fields - Plinian eruptions vesicle textures - magma ascent dynamics

\section{Introduction}

Understanding the dynamics of explosive eruptive events has been the primary goal of the volcanological community for many years, since Plinian style volcanic eruptions represent the most powerful and dangerous expression of volcanism on the Earth. The development of sophis-

Mailing address: Dr. Margherita Polacci, Istituto Nazionale di Geofisica e Vulcanologia, Sede di Pisa, Via della Faggiola 32, 56126 Pisa, Italy; e-mail: polacci@pi.ingv.it

Now at: Istituto Nazionale di Geofisica e Vulcanologia, Sezione di Catania, Piazza Roma 2, 95123 Catania, Italy. ticated numerical codes as well as the implementation of experimental studies has allowed us to move several steps further in quantifying the complex physico-chemical properties of magmas with different compositions and rheological behaviour (Sigurdsson et al., 2000). Furthermore, detailed investigations on recently eyewitnessed eruptions have contributed much to highlight the basic eruptive processes (Newhall and Punongbayan, 1996; Druitt and Kokeelar, 2002). However, monitoring active volcanoes provides geophysical and geochemical data mostly applying to specific eruptions, and numerical simulations or experimental runs are not yet able to reproduce the full range of natural phenomenologies being observed. Textural characterization of pumice clasts has proved to be a valid complementary approach in investigating magmatic processes not directly observable nor 
recognizable from other studies of volcanic deposits. Crystal and vesicle textures have been used as a proxy for the assessment of conditions related to the eruption dynamics (Klug and Cashman, 1996; Hammer et al., 1999; Polacci et al., 2001, 2003; Klug et al., 2002), and for constraining results from both numerical simulations (Polacci et al., 2004) and laboratory experiments of conduit magma flow (Mader et al., 1996, 1997; Blower et al., 2001).

We have conducted detailed textural investigations on pumice clasts from two alkaline explosive eruptions from the Phlegraean Fields, namely Agnano Monte Spina (AMS) and Campanian Ignimbrite $(\mathrm{CI})$. The dataset on pumice textures was then used to constrain results from numerical modeling of conduit magma ascent. The main goal of this research was to investigate conduit processes occurring during alkaline eruptions, and compare the findings with observations coming from calc-alkaline eruptions typical of subduction volcanoes.

Results from the investigation of the juvenile fraction of CI fallout deposits have been reported in a recent paper (Polacci et al., 2003), and here will be summarized and combined with analyses referring to pumice products of AMS to provide a comprehensive picture of the dynamics of alkaline silicic eruptions.

\section{Methods}

The samples analyzed in this study are alkali trachytic pumice clasts from the B1 and D1 Plinian magmatic fallout layers of AMS eruption (Di Vito et al., 1999). Pumices were first classified into different types on the basis of macroscopic features. Subsequently, selected clasts from each pumice type were thin-sectioned for qualitative and quantitative investigation of pumice textures. Images were acquired via optical and scanning electron microscopy at different magnification $(30 x, 125 x$, $250 x, 500 x, 1000 x$ ) to cover the full range of vesicle size, shape, spatial distribution and degree of interconnectivity. Backscattered electron images (BSE) were then made binary and processed with shareware software for image analysis to obtain bulk and groundmass (only vesicles $<200 \mu \mathrm{m})$ crystal-free vesicle measurements. Details of the procedure can be found in Polacci et al. (2001, 2003). Two-dimensional bulk and groundmass vesicularities (area fraction of vesicles), groundmass vesicle number densities (number of vesicles per unit area), average vesicle equivalent diameter $(d$, the diameter of a circle whose area equals that of the vesicle) and deformation $(D=1-b / 1+b$, where 1 and $b$ are the major and minor axes of vesicle best fit ellipse) were computed. Conversion to volumetric vesicle number densities can easily be obtained dividing the areal number densities by the average vesicle diameter. These values were then compared with measurements made on the Campanian Ignimbrite pyroclasts (Polacci et al., 2003) and on pumice clasts from calc-alkaline eruptions from subduction volcanoes (Klug and Cashman 1994; Polacci et al. 2001; Klug et al., 2002; Rosi et al., 2004).

\section{Results}

\subsection{Observation of pumice textures}

According to the morphological features and vesicle characteristics of the investigated samples, we were able to distinguish different pumice types for which we followed the same classification also applied to the CI juvenile fraction (Polacci et al., 2003). 1) «Microvesicular» pumices are mostly equidimensional or angular clasts containing heterogeneous vesicles, and they are the most abundant juvenile component of the deposit. 2) Fairly elongated, typical «tube» pumice clasts are characterized by alignments of highly stretched, deformed vesicles. Evidence of extensively sheared vesicles up to collapse is present in clasts having low aspect ratios (very flattened in the direction parallel to clast elongation). 3) Finally, «expanded» pumices include all pumice clasts presenting extensive vesicle expansion features, and span from extremely vesicular reticulites (>90\% interconnected vesicles) to clasts with inflated-like textures (vesicular core and progressively denser outer margins). Textures intermediate between the three end-member pumice types are common, and transitional steps among different pumice types can be observed. 
Table I. Pumice types from AMS eruption.

\begin{tabular}{|c|c|c|c|}
\hline Pumice type & Clast morphology & Macroscopic texture & Microscopic texture \\
\hline Microvesicular & $\begin{array}{l}\text { Equidimensional } \\
\text { or angular. }\end{array}$ & $\begin{array}{l}\text { Moderately vesicular to vesicular; } \\
\text { max vesicle size }<1 \mathrm{~mm}\end{array}$ & $\begin{array}{c}\text { Heterogeneous vesicles, } \\
\text { elongated/deformed vesicles } \\
\text { coexisting with spherical vesicles. }\end{array}$ \\
\hline Tube & $\begin{array}{l}\text { Elongated; aspect } \\
\text { ratio } 1: 2 \text { to } 1: 4 .\end{array}$ & $\begin{array}{l}\text { Dense to vesicular, alignments } \\
\text { of large }(>1 \mathrm{~mm}) \text { tube vesicles. }\end{array}$ & Elongated, sheared vesicles. \\
\hline Expanded & $\begin{array}{l}\text { Bread-crusted } \\
\text { to reticulites. }\end{array}$ & $\begin{array}{l}\text { Vesicular to extremely vesicular, } \\
\text { extensive expansion features. }\end{array}$ & Highly interconnected vesicles. \\
\hline
\end{tabular}

Table II. Summary of textural measurements.

\begin{tabular}{ccccccc}
\hline \hline \multicolumn{7}{c}{ AMS fallout layer $B 1$ and $D 1$} \\
\hline Pumice type & $\begin{array}{c}\text { Number } \\
\text { measured }\end{array}$ & $\begin{array}{c}{ }^{*} \text { Gm vesicularity } \\
\text { range }\end{array}$ & $\begin{array}{c}{ }^{* *} \text { Bulk vesicularity } \\
\text { range }\end{array}$ & $\begin{array}{c}{ }^{*} \text { Gm vesicle } \\
n \text { density } \\
\text { range }\left(\mathrm{cm}^{-2}\right)\end{array}$ & $\begin{array}{c}{ }^{* * *} \text { Average } \\
\text { gm } d(\mu \mathrm{m})\end{array}$ & $\begin{array}{c}\text { Average } \\
\text { gm } D\end{array}$ \\
\hline$m$ & 10136 & $0.69-0.84(0.78)$ & $0.80-0.88(0.84)$ & $\begin{array}{c}328610- \\
-805330(488354) \\
291290-\end{array}$ & 17.5 & 0.390 \\
$t$ & 1871 & $0.76-0.85(0.82)$ & $0.85-0.91(0.89)$ & $\begin{array}{c}-621637(402025) \\
275250\end{array}$ & 19.7 & 0.433 \\
$e$ & 13024 & $0.41-0.69(0.57)$ & $0.51-0.87(0.70)$ & $-1169230(660697)$ & 0.367 \\
\hline
\end{tabular}

$m, t$, and $e$ indicate microvesicular, tube and expanded pumice types (here $e$ refers only to inflated pumices); Gm is groundmass (average values in parentheses); " vesicles $<200 \mu \mathrm{m} ;{ }^{* *}$ including vesicles $>200 \mu \mathrm{m}$ (phenocrystfree); ${ }^{* * *}$ calculated as $d=2(\phi / N a \pi)^{1 / 2}$, where $\phi$ is vesicularity and $N a$ vesicle number density.

Table I summarizes the observed general macroscopic and microscopic textural characteristics.

\subsection{Quantification of pumice textures}

Bulk and groundmass textural parameters are reported as minimum and maximum, along with the average value, to provide the textural variability within each pumice type (table II). Owing to the difficulty of decoalescing vesicle textures where extreme interconnectivity occurs, highly expanded pumice clasts were not included in this analysis, and only results pertaining to pumices with inflated core and dense margins are reported in table II. Bulk and groundmass vesicularities, as well as groundmass vesicle number densities, span quite a wide range of values for all three pumice types, with the lowest values applying to inflated pumices (table II). On average, tube pumices record the highest bulk (0.89) and groundmass (0.82) vesicularities, but the lowest vesicle number densities $\left(4 \times 10^{5} \mathrm{~cm}^{-2}\right)$. Similar values of vesicle size and deformation are exhibited by all pumice types, with the lowest values pertaining again to inflated pumices (table II).

\section{Discussion}

\subsection{Comparison with pumice textures from calc-alkaline eruptions and feed-back with numerical modeling of conduit magma ascent}

Table III reports data on vesicle measurements related to several well studied sustained 
Table III. Vesicle measurements from explosive silicic eruptions.

\begin{tabular}{cccccc}
\hline \hline Eruption & Pumice type & $\begin{array}{c}\text { Bulk vesicularity } \\
\text { from image analysis }\end{array}$ & $\begin{array}{c}\text { Average density-derived } \\
\text { bulk vesicularity }\end{array}$ & $\begin{array}{c}\text { Average bulk } \\
\text { vesicle } n \text { density }\left(\mathrm{cm}^{-3}\right)\end{array}$ & $\begin{array}{c}\text { Average } \\
\text { gm } D\end{array}$ \\
\hline${ }^{*}$ CI & $m$ & $0.85-0.94(0.89)$ & 0.78 & $1 \times 10^{8}$ & 0.390 \\
& $t$ & $0.87-0.92(0.89)$ & 0.75 & $1 \times 10^{8}$ & 0.591 \\
& $e$ & - & 0.81 & - & - \\
${ }^{* * *}$ Pinatubo & White & $0.76-0.85(0.81)$ & 0.60 & $1 \times 10^{8}-10^{9}$ & 0.371 \\
& Foliated & $0.72-0.82(0.77)$ & - & $1 \times 10^{9}$ & 0.383 \\
& Gray & $0.68-0.82(0.74)$ & 0.66 & $1 \times 10^{8}-10^{9}$ & 0.234 \\
${ }^{* * *}$ Quilotoa & White & $(0.80)$ & 0.66 & $8.9 \times 10^{8}$ & 0.413 \\
& Gray & $(0.84)$ & 0.71 & $8.1 \times 10^{8}$ & 0.274 \\
${ }^{\wedge}$ Mt. Mazama & Different & - & 0.82 & $1.0 \times 10^{9}$ & - \\
& types & & & & \\
$\wedge_{\wedge \wedge}$ Mt. St. Helens & White & $(0.80)$ & 0.80 & $8.2 \times 10^{8}$ & - \\
& Gray & $(0.60)$ & 0.61 & $2.0 \times 10^{9}$ & - \\
\hline
\end{tabular}

$m, t$, and $e$ indicate microvesicular, tube and expanded pumice types; Gm is groundmass (in the third column, average values are given in parentheses); ${ }^{*}$ from Polacci et al. (2003); ${ }^{* *}$ from Polacci et al. (2001), density-derived vesicularities from Pallister et al. (1996); ${ }^{* * *}$ from Rosi et al. (2004); ^ from Klug et al. (2002), 0.82 is helium picnometer vesicularity; ${ }^{\wedge} \wedge$ from Klug and Cashman (1994), 0.80 and 0.61 are helium picnometer vesicularities.

calc-alkaline explosive eruptions: the 1991 climactic Pinatubo eruption (Philippines), the 800-year-BP Quilotoa eruption (Ecuador), the 7700-year-BP Mt. Mazama eruption (Crater lake, Oregon), and the 1980 Mt. St. Helens eruption (Washington), respectively. Data on the CI eruption are also included to allow full comparison with the textural dataset on alkaline eruptions from Phlegraean Fields. Detailed inspections of the juvenile fraction of CI and AMS have revealed that clast morphologies and vesicle textures present close similarities with those exhibited by pumices from the above reported calc-alkaline eruptions, despite their different bulk compositions, volatile and crystal contents. First of all, the bulk of the deposit in eruptions of both magmatic compositions is generally constituted by microvesicular pumice clasts, which contain heterogeneous vesicle populations at various steps in the coalescence process and with varying degrees of deformation ( $m$ and white, tables II and III). A subordinate pumice type is represented by dense to vesicular tube pumices and/or pumices with foliated surfaces, characterized by alignments of highly elongated/stretched vesicles ( $t$ and foliated, tables II and III). Finally, expanded pumice textures, given by the growth and coalescence of poorly deformed vesicles, are also present in clasts of both magma types ( $e$ and gray, tables II and II). Specific measurements on pumice textures report overlapping ranges of vesicle number densities, and similar vesicle size and deformation. Yet vesicularities obtained with image analyses and density-derived vesicularities are higher overall in pumices from CI and AMS in comparison to those from the reported calc-alkaline pyroclasts (table III), with exceptions from Mt. Mazama and Mt. St. Helens helium picnometry values that were measured on a limited number of samples and may be not representative of the whole deposit. If pumice clasts do not exhibit evidence of postfragmentation expansion features, vesicularities can be assumed to represent the state of magma at the time of fragmentation, and differences in vesicularities may therefore record different fragmentation conditions owing to the different magma properties characterizing alkaline and calc-alkaline compositions. 
Recent determination of viscosities of Phlegraean Fields trachytic melts have shown that CI and AMS viscosities may be up to two orders of magnitude lower than those of a typical rhyolite at anhydrous conditions (Giordano et al., 2004). The lower viscosity of these trachytic melts, together with the higher solubilities (Polacci et al., 2004), translate into a different distribution of the flow variables within the conduit and different fragmentation conditions. Figure 1 reports an example of the numerical modeling of magma ascent and fragmentation for a typical rhyolite composition and for trachytic compositions corresponding to the CI and AMS eruptions. Details of the conduit flow model are described elsewhere (Papale, 2001). The gas volume fraction distribution of the rhyolitic magma is different from that of the two trachytic compositions. The rhyolitic magma fragments at a much deeper level in the conduit and at lower gas volume fraction (0.70 versus 0.82 and 0.83 , in this specific case). A similar behaviour is obtained by changing the water content and/or the conduit diameter.
If we take into account vesicularities pertaining to microvesicular pumice clasts, by far the most abundant juvenile component in the deposits from both magma types, differences in calculated trachytic (alkaline) and rhyolitic (calc-alkaline) vesicularities match quite well with results of vesicularities directly measured on natural pumice clasts (table III). Density-derived vesicularities are the best way to statistically represent the vesicularity distribution of the whole deposit (Klug et al., 2002; Polacci et al., 2003), averaging 0.78 for CI pumice clasts, whereas lower values apply to Pinatubo and Quilotoa pumices, 0.60 and 0.66 respectively. The higher vesicularities displayed by both Mt. Mazama and Mt. St. Helens products may not only be the outcome of a limited number of processed samples but, alternatively, may result from magmatic mixtures whose viscosity is lower than that of a typical rhyolite or dacite, due to specific conditions like very poor crystal content (former case) or lower evolved chemical composition (latter case).

By combining the dataset of textural measurements with observations from the numerical

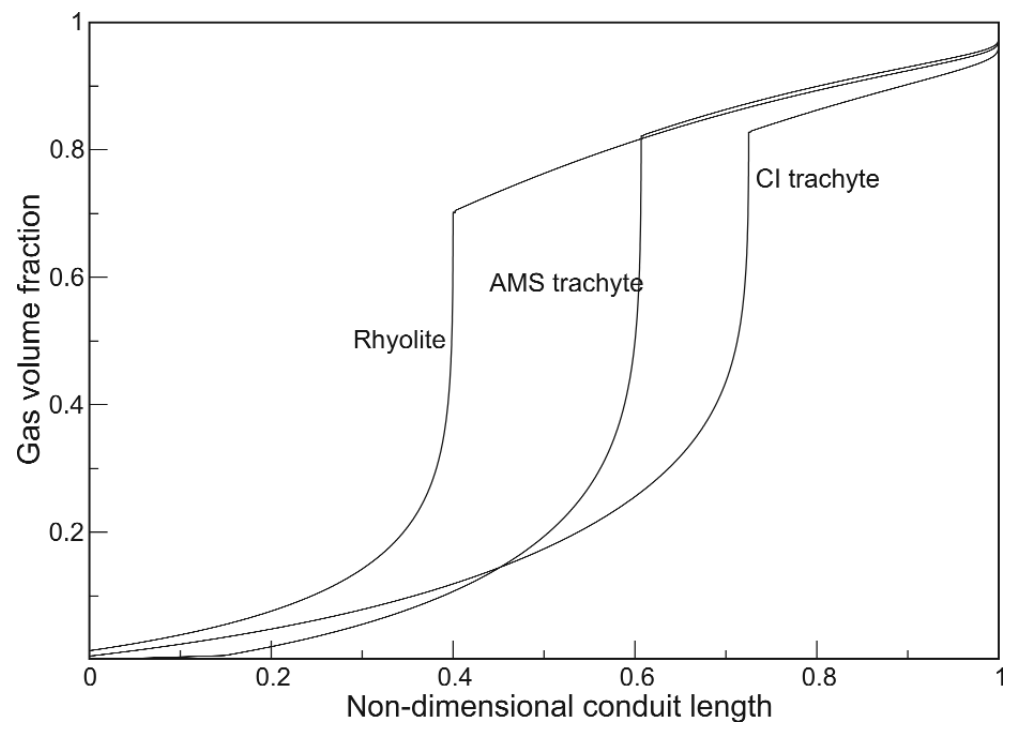

Fig. 1. Calculated distribution of the gas volume fraction along the conduit with the model of Papale (2001). Input parameters are $5 \mathrm{~km}$ conduit length, $122.5 \mathrm{MPa}$ stagnation pressure, $6 \mathrm{wt} \%$ water content, $60 \mathrm{~m}$ conduit diameter and compositions corresponding to that of AMS, CI (Romano et al., 2003; Giordano et al., 2004, respectively) and a typical rhyolite (Innocenti et al., 1982). 
simulations, we have been able to ascribe differences in pumice vesicularity to the different rheological properties of alkaline versus calcalkaline magmas, which, in turn, may affect the flow property distributions within the volcanic conduit. The lower viscosity of alkaline magmas, together with their higher solubilities, implies that the Phlegraean Fields trachytic magma needs to run a longer section of the conduit before reaching the conditions necessary to fragment, eventually allowing further gas exsolution and magmatic mixture expansion in comparison to highly viscous rhyolitic to dacitic magmas.

\subsection{Inferences with eruption dynamics}

Alkaline and calc-alkaline eruptions are characterized by similar eruptive phenomenologies. This indicates that differences in fragmentation conditions do not translate into significantly different flow conditions at the eruptive vent (Polacci et al. 2004). Indeed, the observed similarities in clast morphologies and textures indicate that the origin of pumices from alkaline and calc-alkaline eruptions may be ascribed to the same magmatic processes. Previous studies have interpreted the origin of different pumice types within

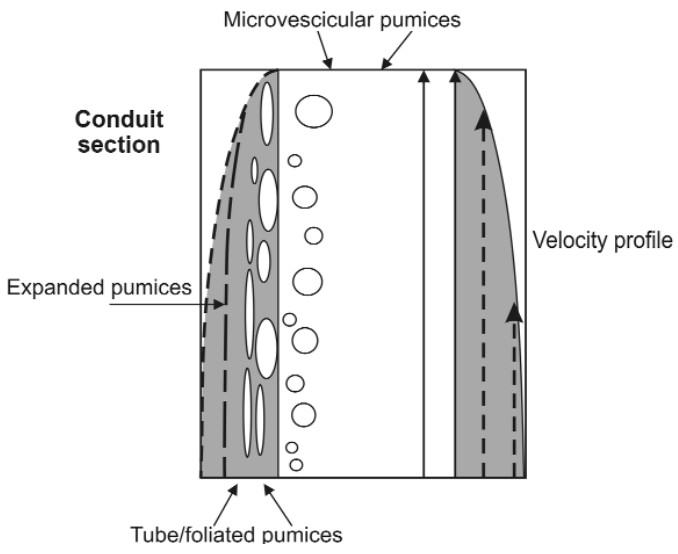

Fig. 2. Zonation of different pumice types within the volcanic conduit, after Polacci et al. (2003). Not to scale. the same eruptive event as due to changes in the eruptive regime (convective versus buoyant) (Klug et al., 2002), or to the development of horizontal gradients of the magma properties within the conduit (Polacci et al., 2001; Rosi et al., 2004). In agreement with the last hypothesis the following horizontal zonation of flow conditions in volcanic conduits is outlined (fig. 2). Assuming a velocity profile, the central part of the conduit is occupied by microvesicular pumice clasts, where vesicles are free to grow only subjected to elongational stresses. Pumices with tube and foliated textures are thought to originate in the region between the center and the conduit walls, where, owing to the exerted shear stress and velocity gradient, vesicles are extensively sheared and deformed until they eventually collapse. Pumices with expansion features are located at the conduit walls, where the shear stress is maximum and where the local temperature and velocity rise by viscous heating (Costa and Macedonio, 2003) produces several related effects from crystal resorption (in crystal-rich eruptions as Pinatubo and Quilotoa) to enhanced volatile exsolution and vesicle growth and coalescence (in low viscosity, high solubility alkaline eruptions as CI and AMS) (Polacci et al., 2001, 2003).

As the three end-member pumice types are related to conduit zones characterized by different magma properties, quantification of their proportion may provide insights into mechanisms of magma exsolution (volatile release from the melt), degassing (volatile separation from the melt), and development of permeability, all of which deeply affect the whole eruption dynamics. Tube pumices and pumices with extensive expansion features have the highest vesicularities and degree of vesicle interconnectivity (Klug et al., 2002; Polacci et al., 2003 , and this paper), and their presence in volcanic deposits may be used as a proxy to infer the ability of the magmatic mixture to develop a permeable network of vesicles through which the gas phase may eventually escape non-explosively. The increase or decrease in the proportion of the different pumice types is therefore likely to reflect a change in the eruption dynamics. This simplified scheme may apply to both alkaline and calc-alkaline eruption dynamics and constrain theoretical results of magma 
flow in volcanic conduits with observations on natural pumice clast textures.

\section{Perspectives}

We have investigated the dynamics of Phlegraean Fields eruptions by combining textural characterization of pumice clasts with observations from numerical modeling. Comparison with data and observations on pumice clasts from calc-alkaline eruptions has allowed us to provide a general scheme of the rhyolitic versus trachytic eruption dynamics. This interdisciplinary approach applied to other alkaline and calc-alkaline eruption compositions promises to represent a tool to constrain the overall dynamics of explosive eruptions. Textural measurements available to date are however limited and do not cover the whole range of crystal and vesicle content present in natural volcanic products. Moreover, numerical simulations of conduit magma flow present several restrictions since, for example, they can be applied to specific eruption conditions (steady or sub-steady), and/or do not model the along-the conduit kinetics of crystal and bubble nucleation and growth or the multiphase magma rheology. Future efforts should therefore be focused on strengthening the existing textural dataset and on implementing numerical codes aimed at reproducing better the observed phenomenologies. Particular emphasis should be placed on measuring textural parameters, like vesicle interconnectivity, specifically linked to the development of magma permeability, which is known to profoundly affect the eruption dynamics (Klug and Cashman, 1996; Papale, 2001). These parameters also represent crucial constraint data for the numerical modeling.

\section{Acknowledgements}

This work was supported by GNV project 2000/02/-17. We wish to thank F. Colarieti for thin section preparation and SEM assistance, and P. Pantani for graphic assistance. Comments from J. Gardner and an anonymous reviewer have been gratefully appreciated.

\section{REFERENCES}

Blower, J.D., J.P. Keating, H.M. Mader and J.C. Phillips (2001): Inferring volcanic degassing processes from vesicle size distributions, Geophys. Res. Lett., 28, 347350.

Costa, A. and G. Macedonio (2003): Viscous heating in fluids with temperature-dependent viscosity: implications for magma flows, Non-linear Proc. Geophys., 10, 545-555.

Di Vito, M. A., R. Isaia, G. Orsi, J. Southon, S. DE Vita, M. D'Antonio, L. PAPPAlardo and M. Piochi (1999): Volcanism and deformation since 12000 years at the Campi Flegrei caldera (Italy), J. Volcanol. Geotherm. Res., 91, 221-246.

DruitT, T.H. and B.P. Kokeelar (2002): The Eruption of the Soufriere Hills Volcano, Montserrat, from 1995 to 1999 (The Geological Society of London), 1-664.

Giordano, D., C. Romano, P. Papale and D.B. Dingwell (2004): The viscosity of trachytes, and comparison with basalts, phonolites, and rhyolites, Chem. Geol., 213, 49-61.

KLug, C. and K.V. CASHMan (1994): Vesiculation of May 18, 1980, Mt. St. Helens magma, Geology, 22, 468-472.

Klug, C. and K.V. CAshman (1996): Permeability development in vesiculating magmas: implications for fragmentation, Bull Volcanol., 58, 87-100.

Klug, C., K.V. Cashman and C.R. Bacon (2002): Structure and physical characteristics of pumice from the climactic eruption of Mt. Mazama (Crater Lake), Oregon, Bull. Volcanol., 64, 486-501.

Hammer, J.E., K.V. Cashman, R.P. Hoblitt and S. NewMAN (1999): Degassing and microlite crystallization during pre-climactic events of the 1991 eruption of Mt. Pinatubo, Philippines, Bull. Volcanol., 60, 355-380

Innocenti, F., P. Manetti, R. Mazzuoli, G. PAsquarè and L. VILLARI (1982): Anatolia and North-Western Iran, in Andesites, edited by R.S. THOrPe (Wiley and Sons, New York), 327-349.

Mader, H.M., J.C. Phillips and R.S.J. Sparks (1996): Dynamics of explosive degassing of magma: observations of fragmenting two-phase flow, J. Geophys. Res., 101, 5547-5560.

Mader, H. M., E.E. Brodsky, D. Howard and B. SturtenVANT (1997): Laboratory simulations of sustained volcanic eruptions, Nature, 338, 462-464.

Newhall, C.G. and R.S. Punongbayan (1996): Fire and Mud: Eruptions and Lahars of Mt. Pinatubo, Philippines (University of Washington press, Seattle), 11126.

PApale, P. (2001): The dynamics of magma flow in volcanic conduits with variable fragmentation efficiency and non-equilibrium pumice degassing, J. Geophys. Res., 106, 11043-11065.

Polacci , M., P. PAPAle and M. Rosi (2001): Textural heterogeneities in pumices from the climactic eruption of Mt. Pinatubo, 15 June 1991, and implications for magma ascent dynamics, Bull. Volcanol., 63, 83-97.

Polacci, M., L. Pioli and M. Rosi (2003): The Plinian phase of the Campanian Ignimbrite eruption (Phlegraean Fields, Italy): evidence from density measurements and textural characterization of pumice, Bull. Volcanol., 65, 418-432. 
Polacci, M., P. Papale, D. Del Seppia, D. Giordano and C. Romano (2004): Dynamics of magma ascent and fragmentation in trachytic versus rhyolitic eruptions, $J$. Volcanol. Geotherm. Res., 131, 93-108.

Romano, C., D. Giordano, V. Mincione, K. U. Hess, D. Dingwell and P. PAPALE (2003): The dry and hydrous viscosities of alcaline melts from Vesuvius and Phlegraean Fields, Chem. Geol., 202, 23-38.
Rosi, M., P. Landi, M. Polacci, A. Di Muro and D. ZanDOMENEGHI (2004): Role of conduit shear on ascent of the crystal-rich magma feeding the 800-year-BP Plinian eruption of Quilotoa Volcano (Ecuador), Bull. Volcanol., 66, 307-321, doi: 10.1007/s00445-003-0312-z.

Sigurdsson, H., B.F. Houghton, S.R. McNutT, H. Rymer and J. STIX (2000): Encyclopedia of Volcanoes (Academic Press, San Diego), 1-1417. 